\title{
The Implementation of Collaborative Writing Technique to Improve Students' Writing Performance and Soft Skill
}

\author{
*1Yanti Sri Rezeki, 2Eka Fajar Rahmani \\ 1-2Universitas Tanjungpura, Indonesia \\ *Correspondence: \\ yanti.sri.rezeki@fkip.untan.ac.id
}

Submission History:

Submitted: June 08, 2021

Revised: August 01, 2021

Accepted: August 06, 2021

This article is licensed under a Creative Commons Attribution 4.0 International License.

\begin{abstract}
The purpose of this study was to look into the use of collaborative writing techniques to help higher secondary students enhance their writing skills and soft skills. This was done based on the findings of earlier studies that showed the effectiveness of collaborative writing techniques in increasing students' writing abilities and soft skills development. Students in Grade 10 at Sekolah Tunas Bangsa Kubu Raya participated in the study, which used a mixed-methods research methodology. For qualitative data, an observation checklist and field note was used, while for quantitative data, a questionnaire and writing tasks were used. The researchers discovered that collaborative writing was effective in improving students' writing proficiency and soft skills after they evaluated and calculated the data. (1) improvements in writing task mean scores from 78.67 in Meeting 1 to 87.13 in Meeting 3; (2) students' responses on a questionnaire about their writing ability and soft skills reached 92 percent in elaborating ideas and 93 percent in gaining self-esteem and confidence; (3) improvements in observation checklists that were performed excellently (scale 4) by the observers on the third meeting; and (4) the note taker's complimentary comments on the field notes about the pupils' writing abilities and soft skills As a result of this data, it is suggested that collaborative writing techniques be used with higher secondary students to improve both writing performance and soft skills.
\end{abstract}

Keywords: collaborative writing, soft skills, writing performance

\section{INTRODUCTION}

Writing is a skill that is needed and employed in a variety of situations throughout one's life (Hidayati, 2018). It is seen to be a useful tool for expressing oneself as well as a physical representation of one's intellectual level in presenting thoughts, feelings, and knowledge (Sadiku, 2015). According to Chappell as cited in Klimova (2012), If students 
write regularly, there are at least seven advantages to writing, including expressing one's personality, fostering communication, developing thinking skills, making logical and persuasive arguments, giving a person the opportunity to later reflect on and re-evaluate his or her ideas, providing and receiving feedback, and preparing for school and employment. In schools, particularly at the secondary level, English writing plays a larger role in everyday chores, projects, quizzes, and even final exams. The complexity of its characteristics and benefits are most likely the main factors. Furthermore, Sadiku (2015) Writing is analogized as a gem to be picked, implying that it is a valuable instrument to help learners build their attitude and improve the ability to convey what they are thinking in written form.

There have been numerous studies in the last ten years on the importance of writing for EFL students. In one correlation research conducted by Hosseini et al. (2013), for instance, there was a substantial association between all students' content scores and their writing abilities. This study found that writing ability was important to EFL students and that it could be a crucial criterion for better academic performance and educational achievement (p. 10). Another example was the qualitative study about the importance and challenge of teaching writing to EFL learners conducted by Nasser (2016) revealed that Writing is vital for EFL learners' language development, especially in terms of fostering learning and critical thinking. It greatly aids students in their acquisition of English as a foreign language. Therefore, he (2016, pp. 200-202) suggested that Teachers had to be very careful and strategic in picking appropriate approaches or procedures for teaching writing; using the wrong technique could result in children failing to learn to write. The last example to consider was a study conducted by Rao (2019)about the significance of writing skills in an English language learning environment. Despite the challenges of teaching it to ELLs, he stated that writing plays a significant part in foreign learners' acquisition of English because it involves sophisticated language aspects such as grammar, spelling, pronunciation, structure, and contextual meaning. So, he (2019) claimed If the learners were successful in writing, they would be successful in the other three English skills as well.

In the Indonesian context, English writing has always been challenging for teachers and students. There is numerous research on this topic, such as Ariyanti (2016), Hidayati (2018); , Toba et al. (2019), and Wahyuningsih (2018), all of which discussed and pointed out comparable results suggesting the importance of mastering writing abilities. Teachers and students, on the other hand, continue to face significant challenges in this area, including less effective teaching techniques, a lack of interesting resources and facilities, teachers' creativity in designing writing activities and exercises in the classroom, teachers' ability in writing had not supported students in learning to write, the significant influence of the students' mother tongue when producing writing, a lack of comprehensive feedback from a teacher, a lack of student awareness of the necessity of writing, and a negative attitude toward writing. Fortunately, the number of studies responding to these 
investigations has increased. Over the last five years, more than ten studies have been published that describe several successful approaches for addressing the above-mentioned writing skill difficulties (i.e. Farida, 2017; Isgiarno et al., 2020; Kartawijaya, 2018; Ranabumi et al., 2017; Septiani, 2018; Yulianti et al., 2019; etc). This enthusiasm on the part of the researchers demonstrates their worry about the inequality in writing ability proficiency in Indonesia.

In light of the foregoing, the researchers of this study would want to contribute to the enrichment of writing skills research for EFL students, as well as to provide an effective writing strategy to teachers for use in their writing classes. The purpose of the research was to see if the collaborative writing (CW) technique could help higher secondary students at Sekolah SPK Tunas Bangsa Kubu Raya improve their writing skills. This school follows two different curricula: National and Cambridge. According to the teachers, the pupils were not only aiming to pass the national exam but also the Cambridge exams as a result of this curriculum mix (i.e IGCSE, A Level, and AS Level). Writing parts were prevalent in these exams, particularly in the English course. As a result, the teachers assigned pupils to complete writing assignments or tasks in all of the lesson's subjects. Individual tasks and activities made up the majority of the tasks and activities. The teachers hoped that by doing so, they would be able to assist the students in becoming more acclimated to writing so that they would have less difficulty when taking the Cambridge exams.

The issue was that the pupils did very little interacting during the writing process. They were required to write independently, and the method or approach forced them to do so. The lack of interaction during class activities was not always beneficial. It may have a harmful psychological influence on students. They would become self-promoters, focusing solely on earning good grades/scores (grade-oriented) rather than forming positive relationships with others. The school's goals included building the IB learner profile, which includes inquirers, knowledgeable, thinkers, communicators, principled, open-minded, compassionate, risk-takers, balanced, and reflective students. Consequently, regardless of the grading system in place, teachers in the writing class were expected to use a methodology or procedure that would allow students to engage with one another. And, Collaborative Writing (CW) was one of the writing strategies that had been explored and evaluated for its efficacy.

The effectiveness of the CW technique from the students' writing quality, students' perceptions, influential factors, and also group dynamic during collaborative writing activities ensured positive results (Rezeki, 2017, p. 25). Collaborative Writing (CW) is a type of collaborative learning that encourages students to work together to produce a writing product (not necessarily group one). Students can work in groups or pairs to apply it, with the main goals of exchanging ideas, peer teaching (such as checking grammatical or writing mechanics), or even offering ideas to enrich the writing, as well as developing social skills like negotiating and open-mindedness (Fung, 2010). The effectiveness of the 
CW approach in boosting students' writing abilities is undeniable. According to Deveci (2018) and (Fung, 2010), Collaborative writing encourages students to take charge of their education, promotes maturity in identifying their learning styles, fosters critical thinking while authoring their writing, and improves social skills.

In line with it, Rahayu (2016) emphasized that Students can readily build ideas and take a review or debate from others throughout the proof-reading step when they write jointly. Furthermore, from the standpoint of the teachers, the CW technique was trusted to assist teachers in managing the class and achieving learning goals in writing classes where teachers acted as facilitators and students acted as agents (Sormunen et al., 2013). The students were the facilitators, and the agents were the students, who were triggered to speak deeply and contribute in sharing knowledge, thoughts, and even educating their friends who were not excellent at English without reluctance using the CW technique (Fung, 2010). They are provided opportunities to interact with one another on various parts of writing (Zhang, 2018). They could also develop social skills, empathy, and openness, as well as listen to and respect the opinions of others (Hammond et al., 2010; Zhang, 2018). The CW technique also promotes kids to be better individuals through collaboration, as they build self-esteem and confidence working in groups because they are resourceful and have equal opportunity to speak (Hillyard et al., 2010).

The researcher did this investigation because of the concerns observed in Grade 10 Sekolah Tunas Bangsa and earlier studies. The study used a mixed-method approach in its implementation. In a broader sense, it is concerned with the same issues as the preceding studies mentioned above, which were concerned with examining and offering a technique for fixing writing problems or increasing students' writing skills. The focus of this study, however, was not just on students' writing performances, but also on soft skills development before and after the CW technique was introduced. This study addressed three research issues in accordance with it: (1) Does the pupils' writing improve after using the CW technique? (2) What soft talents emerge most frequently during collaborative writing? And, third, what are the pupils' reactions to the CW technique? The authors believe that the findings reported in this study will be useful to the intended audience, which includes higher secondary school teachers and other scholars with comparable research interests.

\section{METHOD}

\section{Research Design}

The researchers used a mixed-methods approach to conduct the study. From the processes to the discussion of the results, the mixed-method study design allowed the researchers to have triangulation, complementarity, development, initiation, and expansion towards the data (Creswell, 2014). The goal of combining qualitative and quantitative approaches was to create a more comprehensive or fuller explanation of the data under investigation as being suggested by Creswell, 2014; Creswell \& Plano-Clark, (2007). To 
implement the study, the researchers used Creswell's (2014) concurrent mixed-method design, in which quantitative and qualitative data were collected at roughly the same time.

\section{Research Site and Participants}

Students in Year 10 of Sekolah SPK Tunas BangsaKubu Raya participated in this study. There were a total of 17 pupils in the class. The only higher secondary school in West Kalimantan with an SPK (Satuan Pendidikan Kerjasama) is Sekolah SPK Tunas Bangsa. The SPK word was coined to replace the phrase "international school" with schools that followed an international curriculum, such as Cambridge. The national and Cambridge curricula are used at Sekolah SPK Tunas Bangsa. As a result, English is the primary language in this institution, and students must take not only national but also Cambridge tests, such as IGCSE, A Level, and AS Level. Drafting sections, such as writing a paper or an essay, are common in these international exams.

\section{Tools and Technique of Data Collection and Analysis}

The qualitative approaches in this study used a field note and an observation checklist to collect data on the students' behavior, as well as collaborative writing techniques. The statements in the observation checklist were taken from Fung (2010) and contained the soft and hard skills (i.e. mutual engagement, negotiation, cognitive conflicts, shared knowledge, and speaking portion) that were most prominent throughout the application of the CW approach. The observation employed a 1-4 interval scale, with 1 indicating "Not Performed," 2 indicating "Slightly Performed," 3 indicating "Well Performed," and 4 indicating "Excellently Performed. The students' soft and hard talents were also included in the field note, which was borrowed from Fung (2010). Through narrative and description, the findings of the field note were transcribed, evaluated, and qualitatively explained.

The researchers then utilized a closed-questionnaire and a writing task for the quantitative processes. The statements in the questionnaire were derived from Fung (2010) and Wati (2013). It employed a four-point rating scale: (1) disagree; (2) fairly disagree; (3) agree; and (4) strongly agree. The percentage formula was used to calculate the data from the questionnaire. The results were then turned to charts and thoroughly detailed to show the data's comprehensiveness. Meanwhile, writing examinations were administered at each meeting ( $1^{\text {st }}$ meeting, $2^{\text {nd }}$ meeting 2 , and $3^{\text {rd }}$ meeting) to assess the students' improvement in writing. Teachers devised the test to ensure its reliability. The assignment was a descriptive essay based on a textbook topic. The mean score from each meeting was generated based on the test results. The results were then compared, and the results were then examined in detail to see if there had been any progress in writing.

\section{Research Procedure}

The research procedure are collecting data using an observation checklist and a field note while using the CW technique; distributing the closed-questionnaire after using the CW technique; conducting a semi-structured interview after the questionnaire distribution; 
analyzing the data separately; combining the data analysis results; and evaluating and discussing all of the data as a single outcome after merging the results of the data analysis.

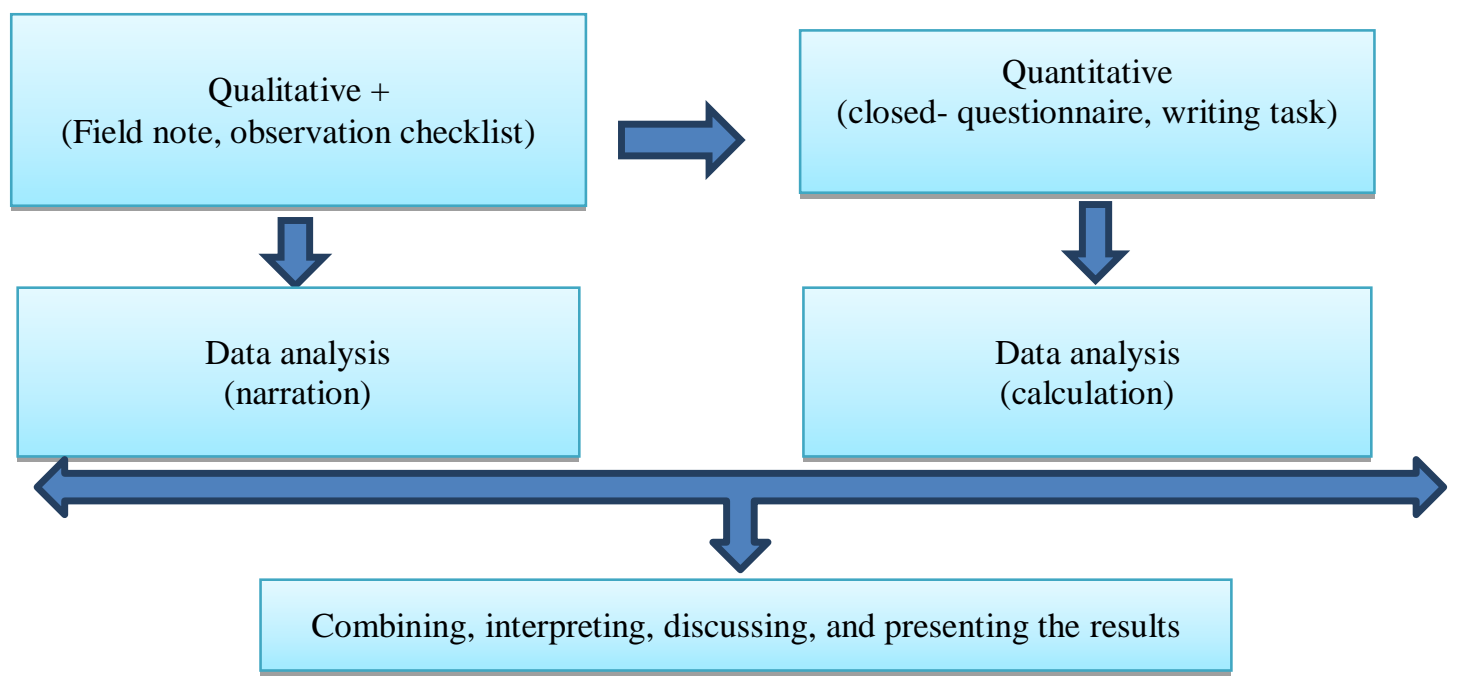

Figure 1. The Flow of the Research

The Collaborative Writing activity was done three times (three meetings) by the researchers. The themes were all drawn from the textbook and varied from meeting to meeting. The pupils were separated into groups of three to four for the implementation. After then, a topic was assigned. They had to talk about it with the rest of the group. During the conversation, they were allowed to use computers to look up information on the internet. This took 60 minutes to complete: 10 minutes for brainstorming, 15 minutes for drafting/outlining, 15 minutes for rewriting, and 20 minutes for editing. The students then had 10 minutes to finish their paper, including proofreading it, and publish or submit it to the lecturers. Following that, the teachers provided input. The researchers used field notes and observation checklists to collect data at all meetings, with the assistance of two assistants. In particular, at $3^{\text {rd }}$ meeting, the researchers gave a questionnaire to find out what the students thought of the CW approach. The researchers meticulously analyzed all of the intended data after gathering it. In the results and discussion portion of this work, the researchers pooled the results of all data, evaluated them, and finally discussed them in-depth.

\section{RESULTS AND DISCUSSION}

The study's findings are presented in this section. It is organized into four sections: questionnaire data analysis, observation checklist, interview, and field note, followed by a discussion section. The discussion delves deeply into the data to respond to the research questions (the foci of the research). As a result, the discussion section is divided into three sections according to the number of research questions. 


\section{Results of Questionnaire Analysis}

The students were asked their thoughts on CW technique from the standpoints of writing talent and soft/social skills. The outcomes are depicted in Figures 2 and 3.

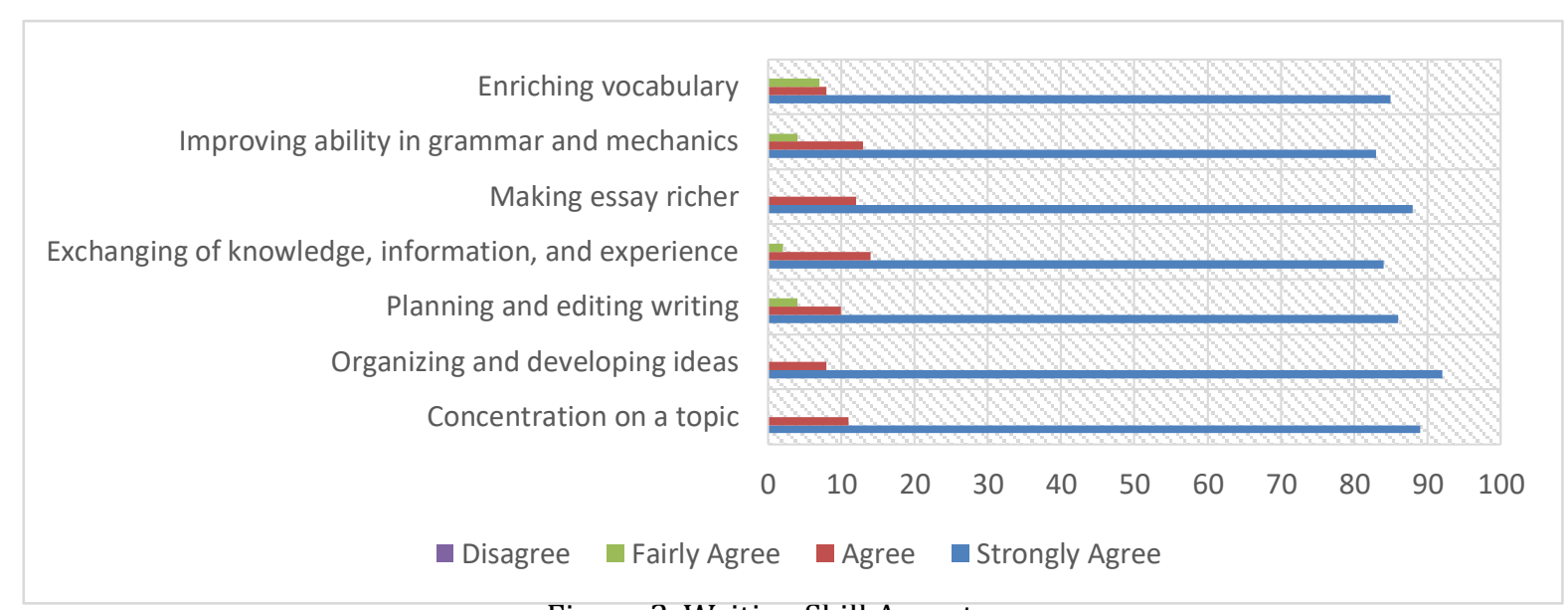

Figure 2. Writing Skill Aspect

Figure 2 shows that none of the students disagreed with any of the seven categories (statements) they were asked to rate. The students, on average, highly agreed that the CW technique has aided them in enhancing their writing skills, particularly in organizing and extending ideas, which received the highest percentage of $92 \%$. Furthermore, the students unanimously agreed that using the CW approach improved their concentrate on a certain issue. With an 89 percent score, this was related to their comprehension of the material. Finally, with an 88 percent confidence level, the students believed that using the CW strategy will enable them to write a richer essay than previously. Based on these findings, it can be stated that the student's writing skills increased dramatically after using the CW technique three times.

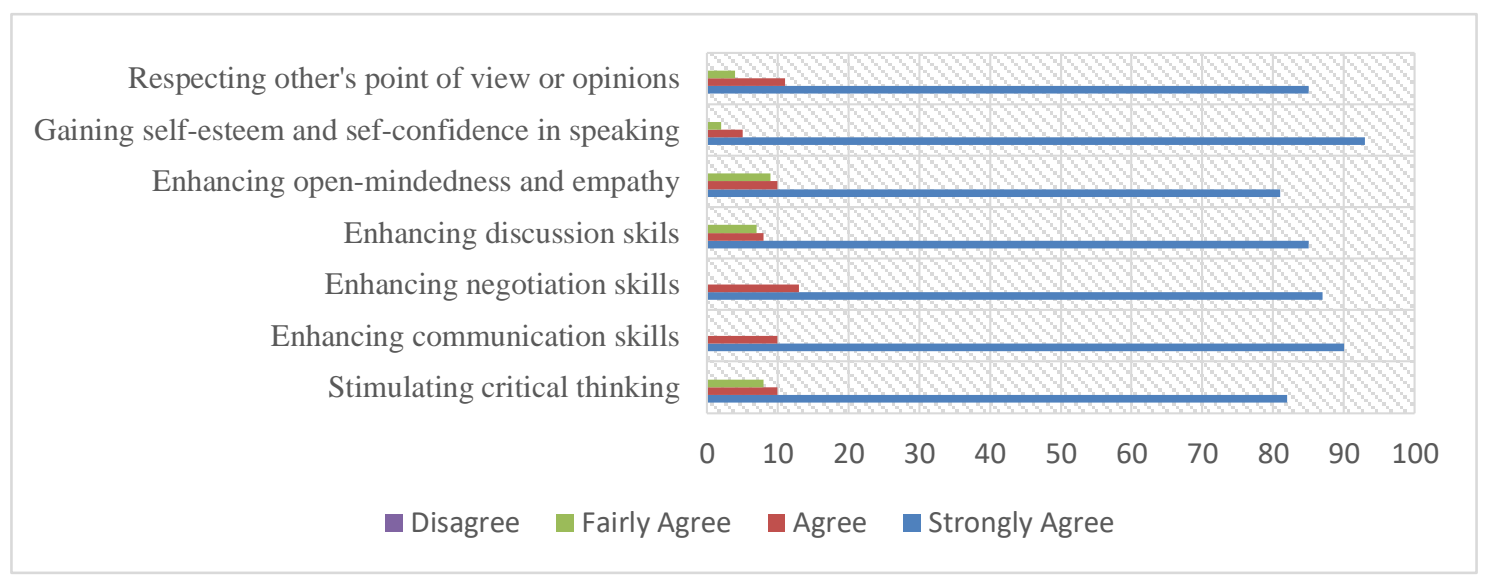

Figure 3. Soft skills aspect

In terms of soft skills, students must respond to seven statements: (1) stimulating critical thinking, (2) improving communication, (3) improving negotiation, (4) improving 
discussion, (5) improving open-mindedness and empathy, (6) improving self-esteem and self-confidence in speaking, and (7) respecting others' points of view. Figure 3 shows that, in terms of soft skills, the CW approach has been successful in considerably improving 4 out of 7 skills. These include (1) increasing self-esteem and self-confidence in speaking by 93 percent; (2) improving communication skills by 90 percent; (3) improving conversation abilities by 87 percent; and (4) improving bargaining skills by 87 percent. In addition, 'strongly agree' was used to reply to the other three soft skills, with an average proportion of 83 percent.

\section{Results of Observation Checklist}

Mutual interaction, negotiation, cognitive conflicts, shared knowledge, and a portion of speech were the five requirements to be observed during the implementation of collaborative writing. During the implementation of $\mathrm{CW}$, the observation was completed in three meetings. The observations were conducted by two observers, and the results are provided in Tables 1 through 3 for each meeting.

Table 1. Observation checklist results from 2 observers (Meeting 1and meeting 2)

\begin{tabular}{llcc}
\hline No. & Aspects & Observer 1 & Observer 2 \\
\hline 1 & While writing, the students engage in mutual & 3 \\
interaction in groups, which involves generating & & 3 \\
ideas, reacting to one another, and creating \\
complements. \\
The students are engaging in group negotiation to \\
establish an agreement on ideas, which includes \\
expressing thoughts and intentions, clarifying and \\
confirming thoughts and intentions, utilizing \\
convincing expressions, and solving a common \\
problem. \\
Cognitive conflicts are seen amongst students in \\
the group which includes using the target language, \\
maintaining thoughts and ideas, and accepting \\
differences of viewpoints (being open-minded) \\
The students are performing shared expertise \\
which includes suggesting ideas of writing, teaching \\
their friends in group (peer-teaching) and \\
contributing ideas to create a more accurate and \\
richer text \\
The students have the same portion of speaking in \\
the group (no one is dominant)
\end{tabular}

Table 1 presents the results of the observation checklist done by two observers in $1^{\text {st }}$ meeting. The Table 1 , it can be seen that both observers observed that mutual interaction (Aspect 1), cognitive conflicts (Aspect 3), and shared expertise (Aspect 4) had 
been well performed indicated by Scale 3 by students. Meanwhile, negotiation aspect (Aspect 2) was observed as slightly performed indicated by Scale 2 by both observers. Then, for the portion of speaking (Aspect 5), 1st Observer and $2^{\text {nd }}$ observer perceived different opinions. $1^{\text {st }}$ observer scaled the aspect by slightly performed indicated by Scale 2 while $2^{\text {nd }}$ Observer scaled the aspect by well performed indicated by Scale 3 . None of the aspects was observed by 4 or by 1 in $1^{\text {st }}$ meeting.

Table 2. Observation checklist results from 2 observers ( $2^{\text {nd }}$ meeting)

\begin{tabular}{|c|c|c|c|}
\hline No. & Aspects & $1^{\text {st }}$ Observer & $2^{\text {nd }}$ Observer \\
\hline 1 & $\begin{array}{l}\text { The Students are performing mutual interaction in } \\
\text { the group while doing the process of writing which } \\
\text { includes initiating ideas, responding to each other, } \\
\text { and developing compliments }\end{array}$ & 4 & 3 \\
\hline 2 & $\begin{array}{l}\text { The students are performing negotiation in their } \\
\text { group to reach an agreement of ideas which } \\
\text { includes expressing thoughts and intentions, } \\
\text { clarifying and confirming thoughts and intentions, } \\
\text { using convincing expressions, and solving a shared } \\
\text { problem }\end{array}$ & 3 & 3 \\
\hline 3 & $\begin{array}{l}\text { Cognitive conflicts are seen amongst students in } \\
\text { the group which includes using the target language, } \\
\text { maintaining thoughts and ideas, and accepting } \\
\text { differences of viewpoints (being open-minded) }\end{array}$ & 4 & 3 \\
\hline 4 & $\begin{array}{l}\text { The students are performing shared expertise } \\
\text { which includes suggesting ideas of writing, teaching } \\
\text { their friends in group (peer-teaching) and } \\
\text { contributing ideas to create a more accurate and } \\
\text { richer text }\end{array}$ & 4 & 4 \\
\hline 5 & $\begin{array}{l}\text { The students have the same portion of speaking in } \\
\text { the group (no one is dominant) }\end{array}$ & 3 & 3 \\
\hline
\end{tabular}

Table 2 presents the results of the observation checklist in $2^{\text {nd }}$ meeting . From Table 2 , we can see that all aspects are scaled by at least well performed indicated by Scale 3 which means the students during discussion or CW implementation showed good progress. In detail, it can be seen that both observers agreed that all students in the group excellently performed expertise (Aspect 4). This indicated that they agreed CW has motivated the students to develop the shared expertise including suggesting ideas of writing, doing peerteaching, contributing ideas to get richer and accurate text. Meanwhile, the aspect of the negotiation (Aspect 2) and the same portion of speaking (Aspect 5) are scaled by wellperformed indicated by Scale 3. Yet, on the aspect of cognitive conflicts (Aspect 5) and mutual interaction (Aspect 1), the observer perceived different opinions. $1^{\text {st }}$ observer agreed to give Scale 4 (excellently performed) while $2^{\text {nd }}$ observer gave Scale 3 (well 
performed). The contrary, on the mutual interaction (Aspect 4), $1^{\text {st }}$ observer scaled it by 4 (excellently performed) while $3^{\text {rd }}$ observer scaled it by 3 (well performed).

Table 3. Observation checklist results from 2 observers (3rd meeting)

\begin{tabular}{|c|c|c|c|}
\hline No. & Aspects & Observer 1 & Observer 2 \\
\hline 1 & $\begin{array}{l}\text { The students are performing mutual interaction in } \\
\text { the group while doing the process of writing which } \\
\text { includes initiating ideas, responding to each other, } \\
\text { and developing compliments }\end{array}$ & 4 & 4 \\
\hline 2 & $\begin{array}{l}\text { The students are performing negotiation in their } \\
\text { group to reach an agreement of ideas which } \\
\text { includes expressing thoughts and intentions, } \\
\text { clarifying and confirming thoughts and intentions, } \\
\text { using convincing expressions, and solving a shared } \\
\text { problem }\end{array}$ & 4 & 4 \\
\hline 3 & $\begin{array}{l}\text { Cognitive conflicts are seen amongst students in } \\
\text { the group which includes using the target language, } \\
\text { maintaining thoughts and ideas, and accepting } \\
\text { differences of viewpoints (being open-minded) }\end{array}$ & 4 & 4 \\
\hline 4 & $\begin{array}{l}\text { The students are performing shared expertise } \\
\text { which includes suggesting ideas of writing, teaching } \\
\text { their friends in group (peer-teaching), and } \\
\text { contributing ideas to create a more accurate and } \\
\text { richer text }\end{array}$ & 4 & 4 \\
\hline 5 & $\begin{array}{l}\text { The students have the same portion of speaking in } \\
\text { the group }\end{array}$ & 4 & 4 \\
\hline
\end{tabular}

Table 3 showed the observation results of two observers in 3rd meeting. From the table, we can see the observers agreed that all aspects (mutual interaction, negotiation, cognitive conflicts, shared expertise, and same portion of speaking) have been performed excellently in 3rd meeting indicated by Scale 4. If we see from first meeting to third meeting, we would comprehend that there happened improvements on each of the soft skills. This means within merely 3 meetings; the CW technique has shown its effectiveness or power to help students not only improve their writing ability aspect, but also their performance on social skills (soft skills).

\section{Result of Field Note}

The field note was used to record the behavior of students during the implementation of CW technique of the three participants within 3 meetings. The field-note taker used a guideline while observing consisting of 5 aspects of soft skills. The field note was aimed to gather more specific data while the CW was being implemented involving (1) mutual interaction in a specific phase of writing, (2) negotiation in a specific phase of 
writing, (3) cognitive conflicts in a specific phase of writing,(4) shared expertise in a specific phase of writing, and (5) problems appeared during collaborative writing.

The students excelled at collaborative features within three meetings, according to the field note results 10 . These groups vividly practice reciprocal interaction, negotiation, cognitive conflicts, and shared knowledge. The characteristics were more prominent in the brainstorming process than in the other four writing phases: drafting, editing, revising, and publishing. According to the notes, there were four issues during the discussion in Meeting 1: (1) students were hesitant to speak up (not confident), (2) one or two students were dominant in all groups, (3) many students expressed concerns or a lack of trust in their friends, and (4) students were upset when their opinions were rejected or not responded to. These issues were addressed in $2^{\text {nd }}$ meeting 2 .

(1) Some kids were still apprehensive to speak up, but not as much as in Meeting 1; only 1 or 2 people in each group were hesitant to voice their ideas, according to the field note-taker. (2) Dominance was identified in fewer groups than in Meeting 1; only two groups had dominance. Students in Meeting 2 were more confident in themselves and their peers. They began to learn how to have a good conversation, including giving and asking for other members' perspectives, and accepting them. There was a lot of progress made in Meeting 3. It was discovered that no concerns had been noted in Meetings 1 and 2. They were a lot more engaged in offering their ideas and whatnot, so the debate was much smoother and livelier. They were certain they understood the goals of the collaborative writing process. Overall, 3rd meeting highlighted soft skills as being very important to acquire.

\section{Result of Writing Task}

The tests were carried out three times, with one test done at each meeting. The assignment was part of a group writing project. It was a result of the students' efforts. Content, organization, vocabulary, grammar, punctuation, and spelling were all evaluated during the writing process. As shown in Table 4, the researcher estimated the mean score from each encounter.

Table 4. Writing mean score

\begin{tabular}{llll}
\hline Task Meeting- & $\mathbf{1}$ & $\mathbf{2}$ & $\mathbf{3}$ \\
\hline Mean Score & 78,67 & 82,33 & 87.13 \\
\hline
\end{tabular}

Table 4 shows that the students' writing abilities have improved after only three visits. Meeting 1 has a mean score of 78.67, meeting 2 has an average score of 82.33, and Meeting 3 has an average score of 87.13. These improvements suggested that the CW technique had an impact on the students' writing skills, despite the fact that the range of scores was not too wide.

The questionnaires, observation checklist, field notes, and writing task findings showed that the CW approach was beneficial in helping Year 10 students improve both their writing competence and soft skills in just three meetings. The students gained a lot of 
experience from the discussion session, which influenced their writing abilities and soft skills at the same time. Although the writing scores did not significantly improve from Meeting 1 to Meeting 3, the soft skills were developed extremely well, as seen by the small mean score range from Meeting 1 to Meeting 3. On the observation checklist, for example, it can be noted that the pupils indicated by Scale 4 excelled in all major components of soft skills (excellently performed). From the students' perspective, the effectiveness of CW was underlined. The students were unanimous in their belief that CW might help them improve their writing talents while also boosting their soft skills (see questionnaire results).

In line with these findings, Zhang (2018) found that collaborative writing was an effective way for students to engage in mutual and sustained interaction and cooperation, shared the decision-making processes, and share accountability. Furthermore, as evidenced by the findings of a study conducted by Fung (2010) students were able to work in groups or pairs with the primary goal of sharing ideas or practicing peer teaching, resulting in a rich writing product and improved writing abilities. The extensive and complicated features that allow students to share ideas, undertake peer teaching, and even suggest ways to help their peers expand their work make collaborative writing potent for improving students' writing skills and developing soft skills (Fung, 2010). The students were triggered or driven to join actively in the conversation, which broke down barriers between good and poor students and increased their self-confidence to speak up (Hillyard et al., 2010; Wati, 2013). Furthermore, students learnt how to listen and respect differences (being open-minded) during the implementation of CW, and they also enriched their knowledge and information from other students (Deveci, 2018; Fong, 2012; Hammond et al., 2010; Laal \& Laal, 2012; Rezeki, 2017; Zhang, 2018).

\section{CONCLUSION}

The purpose of learning EFL is not only to get good grades on high test scores, but also to help students strengthen their social and soft skills. As a result, an interactive technique is critical. In the case of writing, the effectiveness of collaborative writing techniques in improving students' writing ability as well as their social skills is undeniable. According to the findings of this study, the collaborative writing technique is effective in improving the writing abilities and soft skills of higher secondary students after three times deployment. The students did exceptionally well in mutual engagement, negotiation skills, cognitive conflicts, shared knowledge, and balancing portions of speaking throughout the course of three meetings, as seen by their improved writing scores. As a result, it can be concluded that the collaborative technique is highly recommended for higher secondary level because its effectiveness has been scientifically verified.

\section{REFERENCES}

Ariyanti, A. (2016). The teaching of EFL writing in Indonesia. Dinamika IImu, 16(2), 263. https://doi.org/10.21093/di.v16i2.274

Creswell, J. W. (2014). Research design qualitative, quantitative, and mixed methods 
approaches (4th ed.). SAGE Publications, Inc.

Creswell, J. W., \& Plano-Clark, V. . (2007). An introduction to mixed-method research. In Sage Publication. SAGE Publications, Inc.

Deveci, T. (2018). Student perceptions on collaborative writing in a project-based course. Universal Journal of Educational Research, 6(4), 721-732. https://doi.org/10.13189/ujer.2018.060415

Farida, A. I. (2017). Improving students' writing skills through outdoor activity (a Classroom Action Research for the first grade students of SMAN 01 Suruh in Academic Year of 2016/2017). In Thesis, State Institute for Islamic Studies (IAIN) Salatiga. State Institute for Islamic Studies Salatiga.

Fong, L. S. (2012). Benefits of collaborative writing for ESL Advanced Diploma students in the production of reports. 4(4), 396-407.

Fung, Y. M. (2010). Collaborative writing features. RELC Journal, 41(1), 18-30. https://doi.org/10.1177/0033688210362610

Hammond, J. A., Bithell, C. P., Jones, L., \& Bidgood, P. (2010). A first year experience of student-directed peer-assisted learning. Active Learning in Higher Education, 11(3), 201-212. https://doi.org/10.1177/1469787410379683

Hidayati, K. H. (2018). Teaching writing to EFL learners: An investigation of challenges confronted by Indonesian teachers. Langkawi: Journal of The Association for Arabic and English, 4(1), 21. https://doi.org/10.31332/lkw.v4i1.772

Hillyard, C., Gillespie, D., \& Littig, P. (2010). University students' attitudes about learning in small groups after frequent participation. Active Learning in Higher Education, 11(1), 9-20. https://doi.org/10.1177/1469787409355867

Hosseini, M., Taghizadeh, M. E., Abedin, M. J. Z., \& Naseri, E. (2013). In the importance of EFL learners' writing skill: Is there any relation between writing skill and content score of English essay test? International Letters of Social and Humanistic Sciences, 6(September), 1-12. https://doi.org/10.18052/www.scipress.com/ilshs.6.1

Isgiarno, Y. C., Cahyono, B. Y., \& Rahmaningtyas, H. (2020). Increasing EFL students' writing skill using Jigsaw and online searching strategy. IJEE (Indonesian Journal of English Education), 7(1), 97-110. https://doi.org/10.15408/ijee.v7i1.16383

Kartawijaya, S. (2018). Improving students' writing skill in writing paragraph through an outline technique. Curricula, 3(3), 152-158. https://doi.org/10.22216/jcc.2018.v3i3.3429

Klimova, B. F. (2012). The Importance of Writing. Paripex - Indian Journal of Research, 2(1), 9-11. https://doi.org/10.15373/22501991/jan2013/4

Laal, M., \& Laal, M. (2012). Collaborative learning: What is it? Procedia - Social and Behavioral Sciences, 31(December 2012), 491-495. https://doi.org/10.1016/j.sbspro.2011.12.092

Nasser, A. N. A. (2016). Teaching the writing skill to Yemeni EFL learners : The Importance and challenge. South-Asian Journal of Multidisciplinary Studies, 3(6), 191-203. 
Rahayu, E. S. (2016). Using Google Docs on collaborative writing technique for teaching English to non English department students. Proceedings of ISELT FBS Universitas Negeri Padang, 4(1), 226-236. http://ejournal.unp.ac.id/index.php/selt/article/view/6932/5466

Ranabumi, R., Rohmadi, M., \& Subiyantoro, S. (2017). Improving students' writing short story skill through Time Token learning and video media. Journal of Education and Learning (EduLearn), 11(4), 439-445. https://doi.org/10.11591/edulearn.v11i4.6808

Rao, P. S. (2019). The significance of writing skills in ell environment. ACADEMICIA: An $\begin{array}{llll}\text { International Multidisciplinary } & \text { Research }\end{array}$ https://doi.org/10.5958/2249-7137.2019.00035.1

Rezeki, Y. S. (2017). Collaborative written feedback experience: A case study of Indonesian EFL students in an Essay Writing class. International Journal of Educational Best Practices, 1(2), 24. https://doi.org/10.31258/ijebp.v1n2.p24-37

Sadiku, L. M. (2015). The Importance of Four Skills Reading, Speaking, Writing, Listening in a Lesson Hour. European Journal of Language and Literature, 1(1), 29. https://doi.org/10.26417/ejls.v1i1.p29-31

Septiani, P. (2018). Improving students' writing skill by using four square writing technique (a collaborative classroom action research). State Islamic University of Raden Intan Lampung.

Sormunen, E., Tanni, M., \& Heinström, J. (2013). Students' engagement in collaborative knowledge construction in group assignments for information literacy. Information Research, 18(3), 1-16.

Toba, R., Noor, W. N., \& Sanu, L. O. (2019). The current issues of Indonesian EFL students' writing skills: Ability, problem, and reason in writing comparison and contrast Essay. Dinamika Ilmu, 19(1), 57-73. https://doi.org/10.21093/di.v19i1.1506

Wahyuningsih, S. (2018). Challenges and opportunities of teaching academic writing skills: a case study of students at IAIN Kudus. Jurnal Edulingua /, 5(1). https://ejournal.unisnu.ac.id/JE/article/view/820

Wati, N. S. (2013). The effectiveness of collaborative writing method to teach writing skill viewed from students' creativity. Sebelas Maret University.

Yulianti, S., Nuraeni, S., \& Parmawati, A. (2019). Improving students' writing skill using Brainswriting strategy. PROJECT (Professional Journal of English Education), 2(5), 714. https://doi.org/10.22460/project.v2i5.p714-721

Zhang, M. (2018). Collaborative writing in the EFL classroom: The effects of L1 and L2 use. System, 76(4), 1-12. https://doi.org/10.1016/j.system.2018.04.009 